\title{
Structure and Properties of Ca and Zr Containing Heat Resistant Wire Aluminum Alloy Manufactured by Electromagnetic Casting
}

\author{
Nikolay Belov ${ }^{1, *}$, Torgom Akopyan ${ }^{1}$, Natalia Korotkova ${ }^{1}$, Maxim Murashkin ${ }^{2,3}$, Victor Timofeev ${ }^{4}$ \\ and Anastasiya Fortuna ${ }^{5}$ \\ 1 Department of Metal Forming, National University of Science and Technology MISiS, Leninsky Prospekt 4, \\ 119049 Moscow, Russia; nemiroffandtor@yandex.ru (T.A.); kruglova.natalie@gmail.com (N.K.) \\ 2 Institute of Physics of Advanced Materials, Ufa State Aviation Technical University, K. Marx 12, \\ 450008 Ufa, Russia; murashkin.maksim-y@net.ugatu.su \\ 3 Laboratory for Mechanics of Bulk Nanostructured Materials, St. Petersburg State University, \\ Universitetskaya Nab. 7/9, 199034 St. Petersburg, Russia \\ 4 Department of Electrical Engineering, Siberian Federal University, 79 Svobodnyy Prospekt, \\ 660041 Krasnoyarsk, Russia; viktortim0807@mail.ru \\ 5 Department of Physical Materials Science, National University of Science and Technology MISiS, \\ Leninsky Prospekt 4, 119049 Moscow, Russia; anastasya_fortuna@mail.ru \\ * Correspondence: nikolay-belov@yandex.ru; Tel.: +7-9154145945
}

check for

updates

Citation: Belov, N.; Akopyan, T.; Korotkova, N.; Murashkin, M.; Timofeev, V.; Fortuna, A. Structure and Properties of $\mathrm{Ca}$ and $\mathrm{Zr}$ Containing Heat Resistant Wire Aluminum Alloy Manufactured by Electromagnetic Casting. Metals 2021, 11, 236. https://doi.org/10.3390/ met11020236

Academic Editor: Qudong Wang Received: 20 December 2020

Accepted: 26 January 2021

Published: 1 February 2021

Publisher's Note: MDPI stays neutral with regard to jurisdictional claims in published maps and institutional affiliations.

Copyright: (c) 2021 by the authors. Licensee MDPI, Basel, Switzerland. This article is an open access article distributed under the terms and conditions of the Creative Commons Attribution (CC BY) license (https:/ / creativecommons.org/licenses/by/ $4.0 /)$.

\begin{abstract}
Experimental aluminum alloy containing 0.8\% Ca, 0.5\% Zr, 0.5\% Fe and 0.25\% Si (wt.\%), in the form of a long-length rod $12 \mathrm{~mm}$ in diameter was manufactured using an electromagnetic casting $(\mathrm{EMC})$ technique. The extremely high cooling rate during alloy solidification $\left(\approx 10^{4} \mathrm{~K} / \mathrm{s}\right)$ caused the formation of a favorable microstructure in the ingot characterized by a small size of the dendritic cells, fine eutectic particles of Ca-containing phases and full dissolution of $\mathrm{Zr}$ in $\mathrm{Al}$ the solid solution. Due to the microstructure obtained the ingots possess high manufacturability during cold forming (both drawing and rolling). Analysis of the electrical conductivity (EC) and microhardness of the cold rolled strip and cold drawn wire revealed that their temperature dependences are very close. The best combination of hardness and EC in the cold rolled strip was reached after annealing at $450{ }^{\circ} \mathrm{C}$. TEM study of structure evolution revealed that the annealing mode used leads to the formation of $\mathrm{L}_{2}$ type $\mathrm{Al}_{3} \mathrm{Zr}$ phase precipitates with an average diameter of $10 \mathrm{~nm}$ and a high number density. Experimental wire alloy has the best combination of ultimate tensile strength (UTS), electrical conductivity (EC) (200 MPa and 54.8\% IACS, respectively) and thermal stability (up to $450{ }^{\circ} \mathrm{C}$ ) as compared with alloys based on the $\mathrm{Al}-\mathrm{Zr}$ and $\mathrm{Al}$ - rare-earth metal (REM) systems. In addition, it is shown that the presence of calcium in the model alloy increases the electrical conductivity after cold forming operations (both drawing and rolling).
\end{abstract}

Keywords: aluminum-zirconium wire alloys; electromagnetic casting (EMC); drawing; electrical conductivity (EC); phase composition; nanoparticles

\section{Introduction}

For many years, electrical engineering applications have been recognized as one of the main uses of aluminum in terms of industry economics, which is constantly developing under the current widespread tendency for replacing copper conductors [1]. Most conductive $\mathrm{Al}$ alloys are related to 1xxx (Al-Fe-Si), 6xxx (Al-Mg-Si) and 8xxx (Al-Fe) families. For manufacturing electrical parts with appropriate parameters, continuous casting and rolling are currently used for shaping and deformation strengthening. However, the latter is highly reduced after heating to above $\sim 250{ }^{\circ} \mathrm{C}$ due to recrystallization.

For the sake of both improving heat resistance and operating temperature, Al-Zr alloys have been developed for particular applications, like overhead cables for long-distance 
power transmission [2-7]. Transition element $\mathrm{Zr}$ provides a far higher recrystallization temperature (up to $400^{\circ} \mathrm{C}$ ) due to the formation of the nanoscale metastable $\mathrm{Al}_{3} \mathrm{Zr}$ phase with a $\mathrm{L} 1_{2}$ crystal lattice [8-13] while heating to above $350{ }^{\circ} \mathrm{C}$ and decay of solid solution (Al) [14-19]. However, if not controlling the foregoing parameters of melting and casting, the unfavorable $\mathrm{Al}_{3} \mathrm{Zr}$ phase with a $\mathrm{DO}_{23}$ structure may appear. According to the binary $\mathrm{Al}-$ $\mathrm{Zr}$ diagram [6], the liquidus temperature rises dramatically with $\mathrm{Zr}$, hence, the temperature of the melt must be considered depending on the concentration. Additionally, for achieving metastable solubility, a relatively high cooling rate must be provided. The latter may be achieved by techniques like electromagnetic casting (EMC) that is superior to direct chill casting (DC). EMC allows producing long rod billets with far higher surface quality and an exceptionally fine microstructure due to support of the liquid pool by electromagnetic forces, continuous stirring, and increased cooling rates up to $10^{4} \mathrm{~K} / \mathrm{s}$ [20]. Based on the cooling rates, close to rapid solidification techniques [1,21], it may be argued that EMC is a very appropriate method for obtaining high-solute alloys, include those alloyed with transition elements. It was recently demonstrated [22] that $\mathrm{Al}$ alloy containing $0.6 \% \mathrm{Zr}$, $0.4 \% \mathrm{Fe}$ and $0.4 \% \mathrm{Si}$ (wt.\%) may be successfully manufactured by EMC to long-length $12 \mathrm{~mm}$ circular cross-section rods with a microstructure containing Zr-rich solid solution. This structure provided excellent processability in cold drawing down to $3 \mathrm{~mm}$, and the wire product showed a remarkable combination of strength (ultimate tensile strength (UTS) $\sim 230 \mathrm{MPa}$ ) and electrical conductivity (55.6\% IACS), both remaining stable after heating up to $400{ }^{\circ} \mathrm{C}$.

In addition to Fe and Si used, subsequent development can be considered in alloying by rare-earth metal (REM) [21,23] and calcium [24,25]. They are both recognized to be very efficient for improving the heat resistance of $\mathrm{Al}$ alloys. However, while rare earth metals (REM) are more established for $\mathrm{Al}$ alloys, unconventional calcium may bring far higher cost efficiency combined with favoring the physical and mechanical properties. Particularly, it was shown that the $\mathrm{Al}$ wire alloy containing $\mathrm{Al}-4 \% \mathrm{Ca}-1 \% \mathrm{Fe}-0.6 \% \mathrm{Si}-0.2 \%$ $\mathrm{Zr}-0.1 \%$ Sc manufactured from DC cast $150 \mathrm{~mm}$ billet has an improved combination of properties compared with Al-REM alloys [24]. This is due to its structure combining an $\mathrm{Al}$ matrix strengthened by $\mathrm{Al}_{3}(\mathrm{Zr}, \mathrm{Sc})-\mathrm{L}_{2}$ phase particles and uniformly distributed submicron particles of Ca-bearing phases. Simulation of DC casting and flat rolling for the $\mathrm{Al}-0.5 \% \mathrm{Ca}-0.5 \% \mathrm{Fe}-0.25 \% \mathrm{Si}-0.2 \% \mathrm{Zr}-0.1 \% \mathrm{Sc}$ alloy also showed the possibility for achieving such a combination of basic characteristics [25]. In respect to the foregoing compositions, scandium alloying may bring excessive costs of products. Using EMC technology, it is possible to introduce up to $0.6 \% \mathrm{Zr}$, that can be as efficient as the combination of $\mathrm{Zr}$ and Sc. Hence, we find it expedient to consider the $\mathrm{Al}-\mathrm{Ca}-\mathrm{Zr}-\mathrm{Fe}-\mathrm{Si}$ system as the base one. According to our earlier results [5,22,24-26], the target structure can be achieved in the alloy containing $\sim 1 \% \mathrm{Ca}, 0.5 \% \mathrm{Zr}, 0.5 \% \mathrm{Fe}, 0.25 \% \mathrm{Si}$ (wt. \%). Based on above, the goal of the present work is to study the structure, mechanical properties and electrical conductivity of the aluminum wire alloy of the foregoing composition manufactured by direct cold drawing from an as-cast $12 \mathrm{~mm}$ circular cross-section EMC rod and subjected to various heat treatment routes.

\section{Experimental Methods}

Experimental aluminum alloy in the form of a long-length rod $12 \mathrm{~mm}$ in diameter and $\approx 20 \mathrm{~m}$ in length was manufactured using electromagnetic casting (EMC) technique (equipment of the Research and Production Centre of Magnetic Hydrodynamics (Krasnoyarsk, Russia) [27]). The alloy was prepared from commercial aluminum (99.5 wt.\%). Calcium, zirconium, iron and silicon were introduced into the aluminum melt at $880-900{ }^{\circ} \mathrm{C}$ in the form of master alloys. The casting was carried out at a temperature of $\approx 830^{\circ} \mathrm{C}$ which was higher than the alloy liquidus $\left(810^{\circ} \mathrm{C}\right)$. The fragment of long rod billet (Figure 1a) was used for experimental study. According to spectral analysis made using Oxford Instruments, the actual chemical composition of the experimental alloy (hereinafter referred to as ACZ) was close to the target one (Table 1). For a more detailed analysis of the quaternary Al-Ca-Fe-Si 
system, additional studies of the microstructure of the ACZ alloy obtained during slow solidification (melt cooling rate is $\sim 0.01 \mathrm{~K} / \mathrm{min}$ ) were carried out. From this, we can expect the formation of the phase composition close to the equilibrium one.

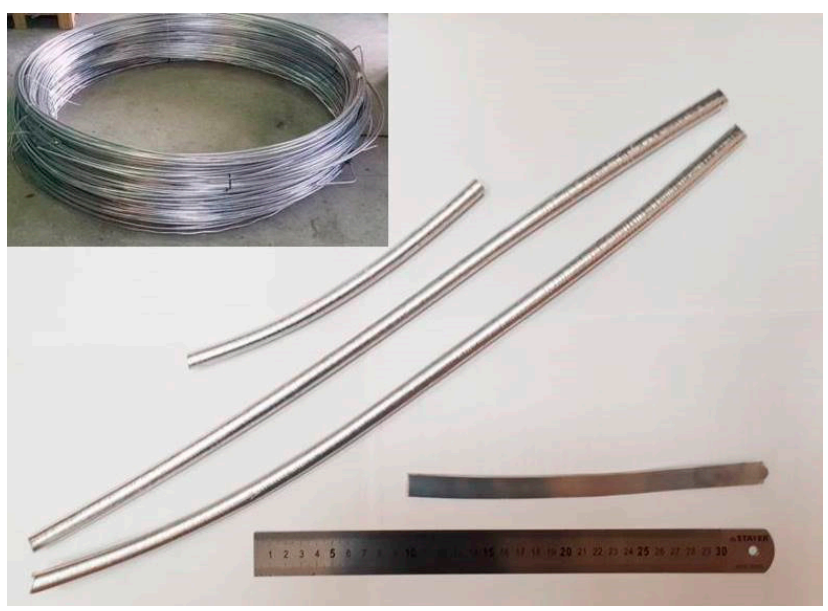

(a)

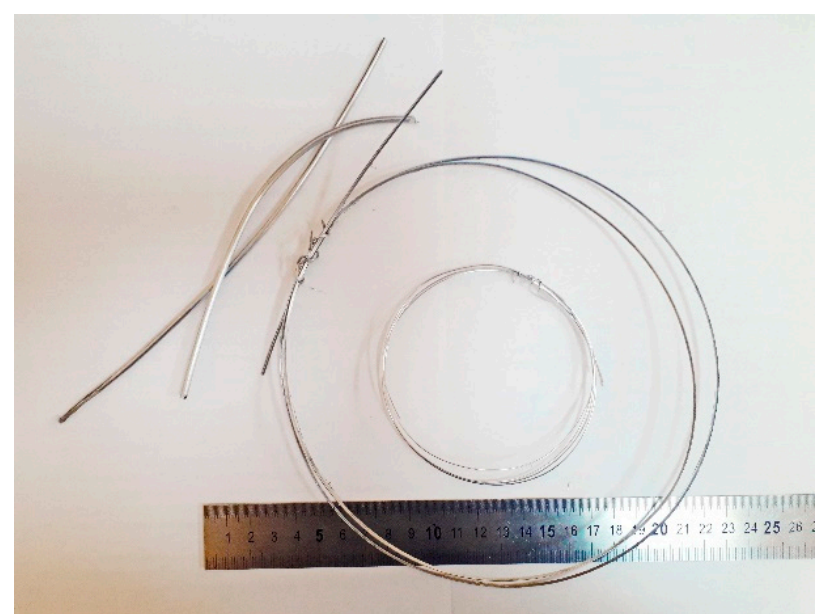

(b)

Figure 1. As-cast wire rod (12 mm) and cold rolled strip (a), and (b) cold drawn wire of ACZ alloy.

Table 1. Chemical compositions of experimental alloys.

\begin{tabular}{cccccc}
\hline \multirow{2}{*}{ Designation } & \multicolumn{5}{c}{ Concentration, wt.\% (at.\%) } \\
\cline { 2 - 6 } & $\mathbf{C a}$ & $\mathbf{F e}$ & $\mathbf{S i}$ & $\mathbf{Z r}$ & $\mathbf{A l}$ \\
\hline $\mathrm{ACZ}$ & $0.81 \pm 0.02(0.55)$ & $0.48 \pm 0.03(0.23)$ & $0.24 \pm 0.02(0.23)$ & $0.46 \pm 0.05(0.14)$ & balance \\
$0 \mathrm{Ca}$ & - & $0.68 \pm 0.04(0.40)$ & $0.23 \pm 0.03(0.22)$ & - & balance \\
$0.1 \mathrm{Ca}$ & $0.13 \pm 0.02(0.09)$ & $0.67 \pm 0.03(0.33)$ & $0.22 \pm 0.03(0.21)$ & balance \\
$0.2 \mathrm{Ca}$ & $0.19 \pm 0.02(0.10)$ & $0.65 \pm 0.04(0.33)$ & $0.21 \pm 0.03(0.20)$ & - & balance \\
$0.75 \mathrm{Ca}^{1}$ & $0.73 \pm 0.03(0.42)$ & $0.41 \pm 0.04(0.20)$ & $0.15 \pm 0.03(0.14)$ & - & balance \\
$1 \mathrm{Ca}^{1}$ & $1.03 \pm 0.04(0.69)$ & $0.41 \pm 0.05(0.20)$ & $0.16 \pm 0.04(0.16)$ & - & balance \\
\hline
\end{tabular}

${ }^{1} \mathrm{Zr}$-free alloys (0-1 wt.\% Ca) were prepared in a resistance furnace (GRAFICARBO) in a form of flat ingots (10 $\mathrm{mm} \times 40 \mathrm{~mm} \times 180 \mathrm{~mm}$ in size) and considered in section "Discussion".

The as-cast EMC rod was processed using drawing (the reduction ratio was $94 \%$ ) to obtain the wire ( $3 \mathrm{~mm}$ diameter, see in Figure $1 \mathrm{~b}$ ). The obtained wire was subjected to annealing at $350-450{ }^{\circ} \mathrm{C}$ together with the $2 \mathrm{~mm}$ strip (Figure 1a) made additionally from the as-cast EMC rod by cold rolling (using a Chinetti LM160 laboratory-scale rolling mill machine). This strip was prepped for the analysis of the influence of deformation on the decomposition of (Al) during annealing. The stepwise annealing modes (Table 2) used for all experimental samples (EMC rod, wire and strip) were previously substantiated [22]. The Vickers hardness and electrical conductivity (EC) of the samples were measured at each annealing step. The measurement was carried out at room temperature.

Besides, the ternary and 4 quaternary alloys containing $0.5 \% \mathrm{Fe}, 0.25 \% \mathrm{Si}$ and up to $1 \%$ Ca were prepared to estimate the effect of calcium on the electrical conductivity. These alloys were poured at $750{ }^{\circ} \mathrm{C}$ into a flat graphite mold (of $10 \mathrm{~mm} \times 40 \mathrm{~mm} \times 180 \mathrm{~mm}$ in size). The cold rolled sheet products of $2 \mathrm{~mm}$ thickness were prepared from as-cast ingots.

The microstructure was studied using scanning electron microscopy (SEM, TESCAN VEGA 3, Tescan Orsay Holding, Brno, Czech Republic), electron microprobe analysis (EMPA, OXFORD Aztec, Oxford Instruments, Oxford shire, UK), and transmission electron microscopy (TEM, JEM 2100, JEOL, Tokyo, Japan). Mechanical polishing was used together with electrolytic polishing, which was carried out at a voltage of $15 \mathrm{~V}$ at a temperature of $-25{ }^{\circ} \mathrm{C}$ in an electrolyte containing $20 \%$ nitric acid and $80 \%$ methanol. The thin foils for 
TEM were prepared by ion thinning with a PIPS (Precision Ion Polishing System, Gatan, Pleasanton, CA, USA) machine and studied at $160 \mathrm{kV}$.

Tensile tests for as-processed wire specimens were conducted by using a universal testing machine, model Zwick Z250 (Zwick Roell AG, Ulm, Germany). The Vickers hardness (HV) was measured using a MetkonDuroline MH-6 (METKON Instruments Inc., Bursa, Turkey) universal tester. A load of $1 \mathrm{~kg}$ and a holding time of $10 \mathrm{~s}$ were used to determine the Vickers hardness. The hardness was measured at least five times at each point.

The specific electrical conductivity (EC) of the EMC rod and the cold rolled strip was determined using the eddy current method with a VE-26NP eddy structures instrument (CJSC Research institute of introscopy SPEKTR, Moscow, Russia). The electrical resistivity of the cold drawn wire was measured for straightened samples of at least $1 \mathrm{~m}$ in length in the rectified part (in accordance with IEC 60468:1974 standard [28]).

Table 2. Annealing regimes for electromagnetic casting (EMC) rod, strip and wire.

\begin{tabular}{|c|c|}
\hline Designation & Regime Treatment \\
\hline \multicolumn{2}{|c|}{ R-EMC casting rod (diameter $12 \mathrm{~mm}$ )/S-cold rolled strip (thickness $2 \mathrm{~mm}$ ) } \\
\hline $\mathrm{R} / \mathrm{S}$ & As-cast/as-cold rolled \\
\hline $\mathrm{R} 300 / \mathrm{S} 300$ & Annealing at $300^{\circ} \mathrm{C}, 3 \mathrm{~h}$ \\
\hline $\mathrm{R} 350 / \mathrm{S} 350$ & $\mathrm{R} 300 / \mathrm{S} 300+$ annealing at $350^{\circ} \mathrm{C}, 3 \mathrm{~h}$ \\
\hline $\mathrm{R} 400 / \mathrm{S} 400$ & R350/S350 + annealing at $400^{\circ} \mathrm{C}, 3 \mathrm{~h}$ \\
\hline $\mathrm{R} 450 / \mathrm{S} 450$ & R400/S400 + annealing at $450^{\circ} \mathrm{C}, 3 \mathrm{~h}$ \\
\hline R500/S500 & R450/S450 + annealing at $500^{\circ} \mathrm{C}, 3 \mathrm{~h}$ \\
\hline R550/S550 & $\mathrm{R} 500 / \mathrm{S} 500+$ annealing at $550{ }^{\circ} \mathrm{C}, 3 \mathrm{~h}$ \\
\hline $\mathrm{R} 600 / \mathrm{S} 600$ & $\mathrm{R} 550 / \mathrm{S} 550+$ annealing at $600^{\circ} \mathrm{C}, 3 \mathrm{~h}$ \\
\hline \multicolumn{2}{|c|}{ W-Wire (diameter $3 \mathrm{~mm}$ ) manufactured by cold drawing of as-cast EMC rod } \\
\hline W & As-drawn \\
\hline W350 & $\mathrm{W} 300+$ annealing at $350^{\circ} \mathrm{C}, 3 \mathrm{~h}$ \\
\hline W400 & W350 + annealing at $400^{\circ} \mathrm{C}, 3 \mathrm{~h}$ \\
\hline W450 & $\mathrm{W} 450+$ annealing at $450^{\circ} \mathrm{C}, 3 \mathrm{~h}$ \\
\hline
\end{tabular}

\section{Results}

\subsection{Characterization of as-Cast Structure}

The extremely high cooling rate during ACZ alloy solidification caused the formation of a favorable microstructure (Figure 2a) characterized by small size of dendritic cells, fine eutectic particles of Ca-containing phases and full dissolution of $\mathrm{Zr}$ in Al solid solution. The measured average size of the dendritic cells is $\sim 4 \mu \mathrm{m}$ (Figure $2 \mathrm{~b}$ ) which, according to other studies $[22,29,30]$, corresponds to a cooling rate of $\sim 10^{4} \mathrm{~K} / \mathrm{s}$. Calcium-bearing eutectic particles corresponding to the quaternary eutectic (Al) $+\mathrm{Al}_{4} \mathrm{Ca}+\mathrm{Al}_{10} \mathrm{CaFe}_{2}+\mathrm{Al}_{2} \mathrm{CaSi}_{2}$ [26] are detected in the form of thin veins located along the boundaries of the aluminum dendritic cells. It should be noted that the as-cast structure does not contain needle-shaped inclusions, for example, iron-containing ones.

Remelting of EMC rod followed by pouring into a graphite mold (cooling velocity about $20 \mathrm{~K} / \mathrm{s}$ ) leads to coarsening of structure and the formation of some needle-like particles (Figure 2c). On the other hand, the structure of the alloy after slow solidification (in a furnace) differs considerably from that of the initial EMC rod. Along with the expected general coarsening of the structure, the phase composition of the alloy changes. In particular, needle-shaped $\mathrm{Al}_{3}$ Fe phase inclusions and segregation of primary $\mathrm{Al}_{3} \mathrm{Zr}$ phase crystals (Figure 2d) that are absent in the EMC rod structure can be identified (Figure 2a,b) after slow solidification. 


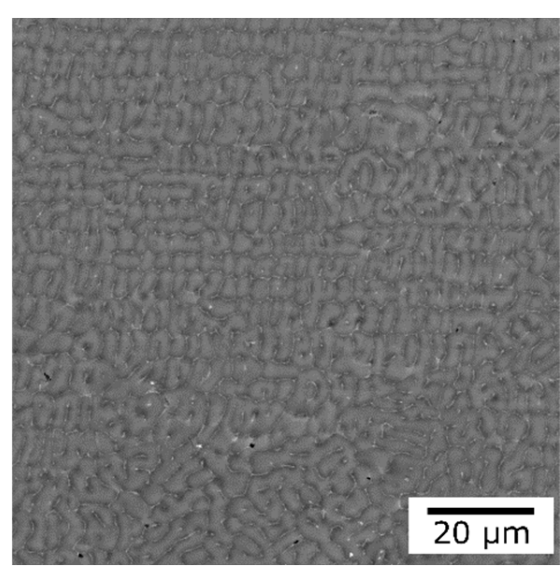

(a)

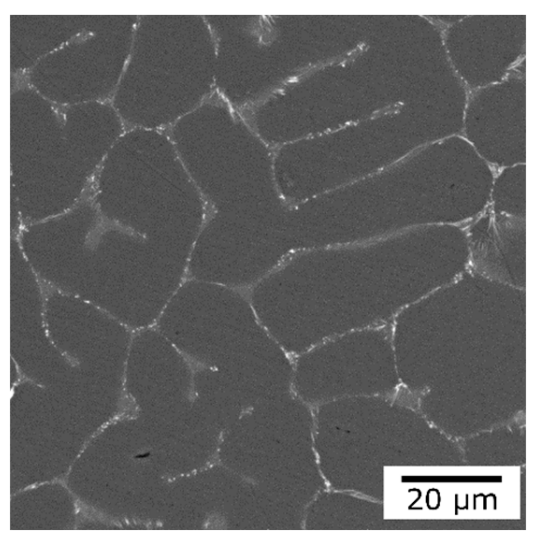

(c)

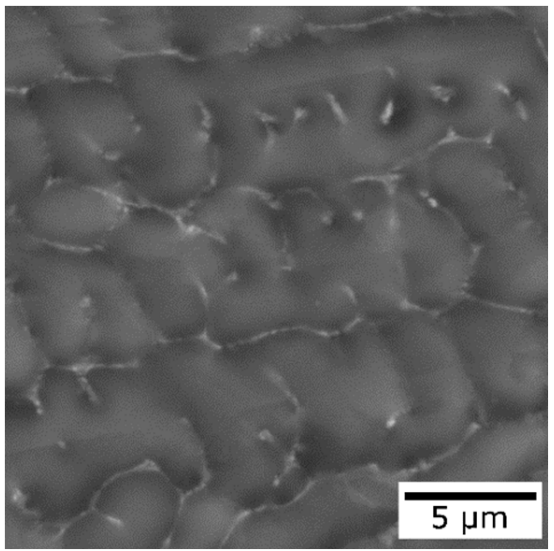

(b)

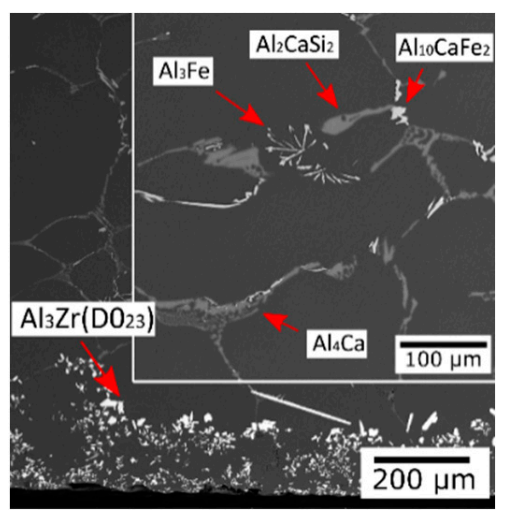

(d)

Figure 2. As-cast microstructure of alloy ACZ after various cooling velocities, SEM: $(\mathbf{a}, \mathbf{b}) \sim 10^{4}(12 \mathrm{~mm}$ EMC rod, $\mathrm{R}$ in Table 2), (c) $\sim 20 \mathrm{~K} / \mathrm{s}(10 \mathrm{~mm} \times 40 \mathrm{~mm} \times 200 \mathrm{~mm}$ ingot), (d) $\sim 0.1 \mathrm{~K} / \mathrm{s}$ (cooling in furnace).

\subsection{Effect of Cold Deformation and Annealing on Structure, Hardness and Electrical Conductivity}

Due to the fine structure of the eutectic, the as-cast EMC rod possesses high ductility, even during cold forming. During both rolling and drawing, apart from the formation of a fibrous grain structure, fragmentation of Ca-containing eutectic particles can also be observed. Their size is not greater than 1 micron and they are uniformly distributed in the aluminum matrix (Figure 3a,b). Annealing at up to $450{ }^{\circ} \mathrm{C}$ inclusively does not lead to a significant change in the size of Ca-containing eutectic particles. However, the structure remains non-recrystallized. Coarsening of particles is observed at higher temperatures (Figure 3c,d).

As expected, cold deformation leads to a hardening of the ACZ alloy-the hardness increases up to $65 \mathrm{HV}$ for strip and up to $70 \mathrm{HV}$ for wire (states $\mathrm{R}$ and $\mathrm{W}$, respectively, see Table 3). A surprising result is a significant increase in the electrical conductivity-up to $\sim 25 \mathrm{MS} / \mathrm{m}$ (both for strip and wire). In an earlier study for a Ca-free $\mathrm{Al}-0.6 \% \mathrm{Zr}-0.4 \%$ Fe- $0.4 \%$ Si alloy obtained by a similar process, this effect was not observed [22].

According to EMC rod hardness data obtained during annealing (Figure 4a), hardening reaches the highest level at $450{ }^{\circ} \mathrm{C}$ annealing stage temperature (the R450 state). Further increase in the annealing temperature leads to a significant decrease in HV, which is mainly due to the coarsening of the $\mathrm{Al}_{3} \mathrm{Zr}$ precipitates [5-11,16]. Deformation hardening was retained upon strip annealing to $450{ }^{\circ} \mathrm{C}$. At this temperature, the hardness of the EMC rod is the same as for the cold rolled strip (Figure 4a). Further increase in the annealing temperature leads to a significant softening due to the formation of a recrystallized structure. At the maximum annealing temperature used, $600^{\circ} \mathrm{C}$, they had approximately the same 
hardness $(32-33 \mathrm{HV})$ due to the coarsening and transformation of the $\mathrm{Al}_{3} \mathrm{Zr}$ precipitates to the equilibrium $\mathrm{D}_{23}$ phase $[6,15]$.

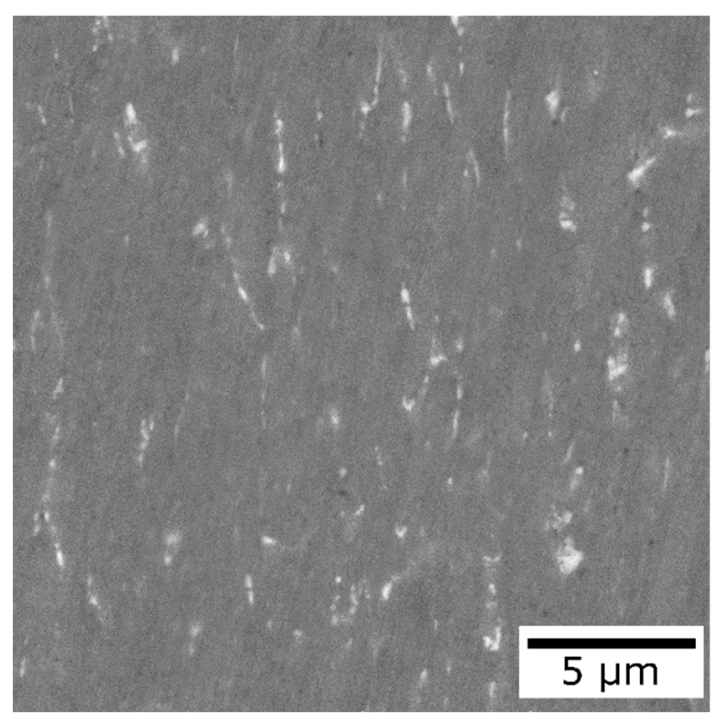

(a)

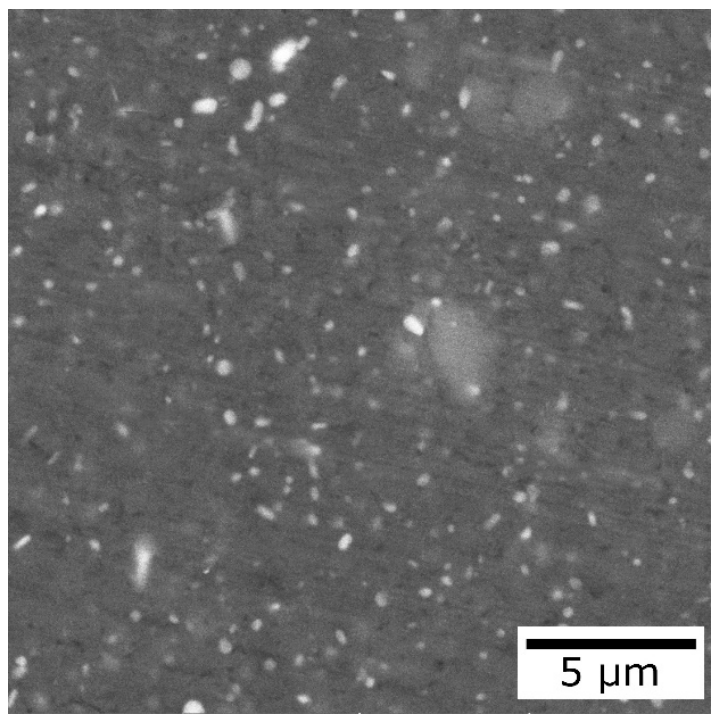

(c)

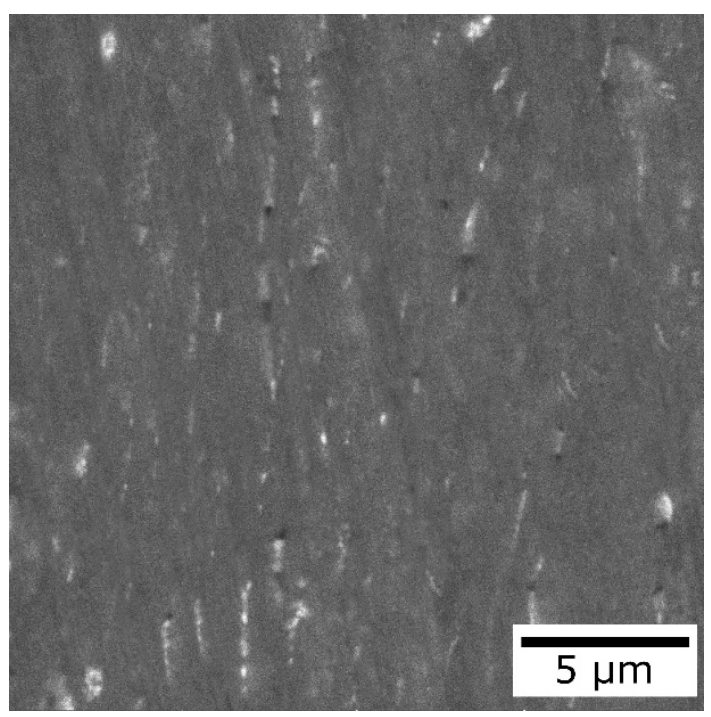

(b)

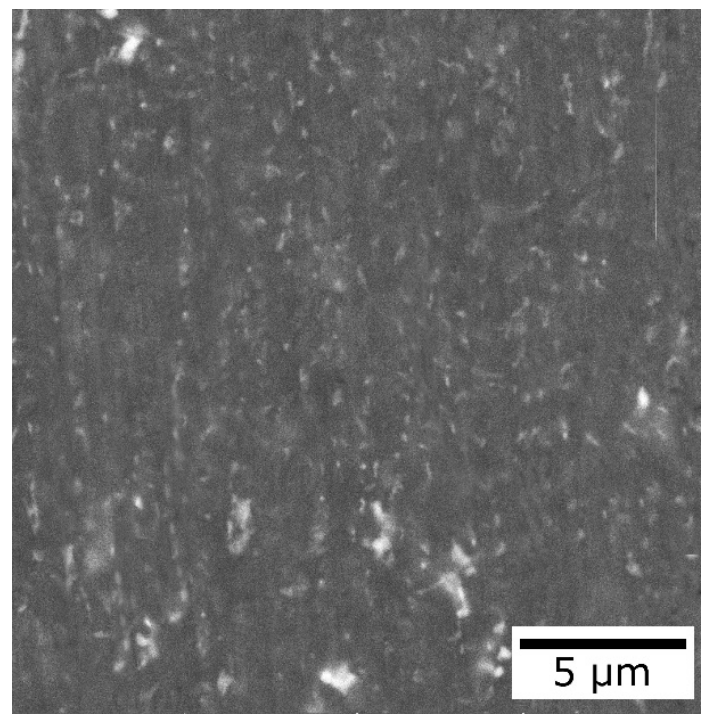

(d)

Figure 3. Microstructure of wire alloy ACZ in (a,c) $3 \mathrm{~mm}$ wire and (b,d) $2 \mathrm{~mm}$ strip: (a), as-drawn, (b) as-rolled, (c,d) annealed at $600{ }^{\circ} \mathrm{C}, \mathrm{SEM}$, (a) W, (b) S, (c) W600, (d) S600, designations see Table 2.

Table 3. Mechanical and electrical properties of ACZ wire alloy.

\begin{tabular}{cccccccc}
\hline \multirow{3}{*}{ State } & \multicolumn{3}{c}{ Mechanical Properties } & \multicolumn{3}{c}{ Electrical Properties } \\
\cline { 2 - 8 } & $\begin{array}{c}\text { YS, } \\
\text { MPa }\end{array}$ & $\begin{array}{c}\text { UTS, } \\
\text { MPa }\end{array}$ & $\begin{array}{c}\text { El, } \\
\text { \% }\end{array}$ & $\begin{array}{c}\text { HV, } \\
\text { MPa }\end{array}$ & $\begin{array}{c}\text { ER, } \\
\text { n } \mathbf{m}\end{array}$ & $\begin{array}{c}\text { EC, } \\
\text { MS/m }\end{array}$ & $\begin{array}{c}\text { EC, } \\
\text { \%IACS }\end{array}$ \\
\hline W & $246 \pm 12$ & $282 \pm 7$ & $4.1 \pm 0.4$ & $70 \pm 3$ & 40.26 & 24.8 & 42.9 \\
W350 & - & - & - & - & 36.10 & 27.7 & 47.8 \\
W400 & $197 \pm 2$ & $218 \pm 1$ & $8.9 \pm 2.5$ & $64 \pm 3$ & 34.24 & 29.2 & 50.4 \\
W450 & $181 \pm 6$ & $202 \pm 1$ & $11.9 \pm 1.3$ & $60 \pm 2$ & 31.54 & 31.7 & 54.7 \\
\hline
\end{tabular}


Decomposition of the aluminum solid solution with the formation of $\mathrm{L}_{2}\left(\mathrm{Al}_{3} \mathrm{Zr}\right)$ nanoparticles during annealing promotes the increase in electrical conductivity (EC), as shown in Figure $4 \mathrm{~b}$. At the same time, the difference between the EC values for the EMC rod and for the $2 \mathrm{~mm}$ strip remains approximately the same at all annealing temperatures up to $500{ }^{\circ} \mathrm{C}$ inclusively $(2.5-3.0 \mathrm{MS} / \mathrm{m})$. At this temperature, the maximum EC for a $2 \mathrm{~mm}$ strip is reached, but it corresponds to the softening stage (Figure 4a). Considering the maximum hardness and high electrical conductivity in the cold rolled strip after annealing at $450{ }^{\circ} \mathrm{C}$, we used the same heat treatment for the prepared wire.

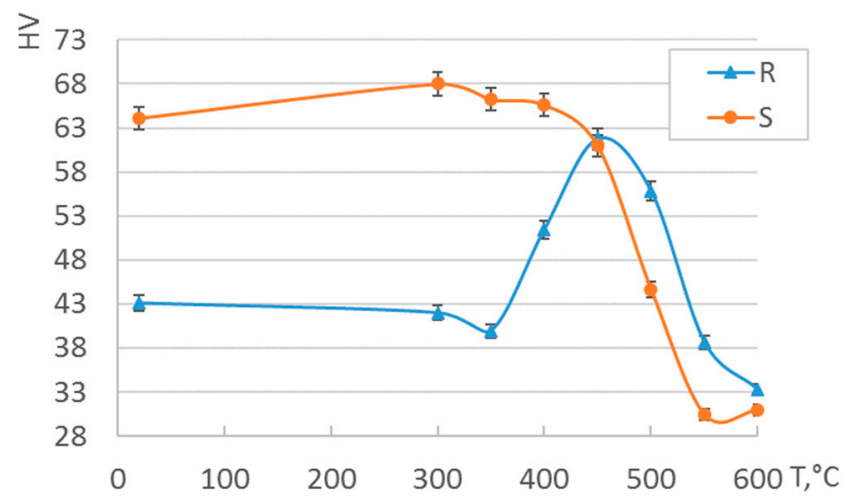

(a)

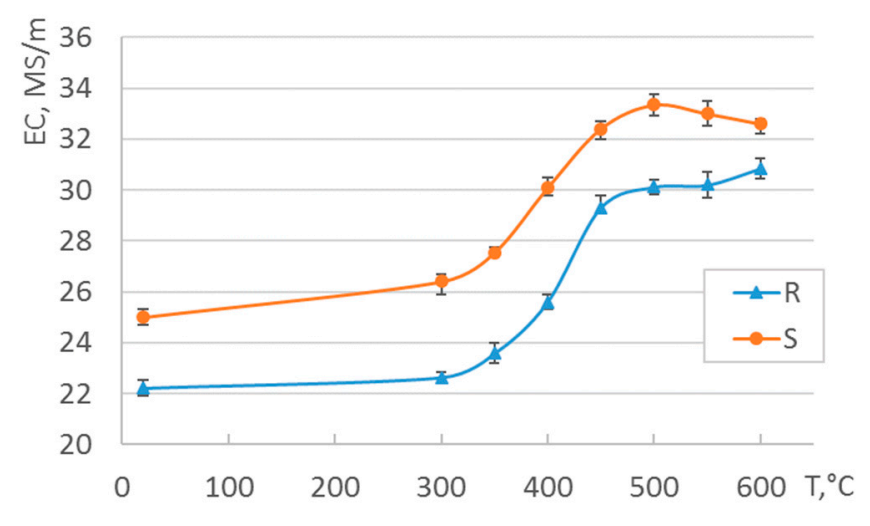

(b)

Figure 4. (a) Hardness (HV) and (b) electrical conductivity (EC) curves for EMC rod (R) and cold rolled strip (S) subjected to stepwise annealing in accordance with the processing route shown in Table 2 (see $\mathrm{R}$ (temperature)/S (temperature) designation).

TEM microstructure of the ACZ alloy was examined for cold rolled strip in the S350 ${ }^{\circ} \mathrm{C}$ (Figure 5a,b) and S450 ${ }^{\circ} \mathrm{C}$ (Figure 5c,d) states to confirm the main structure changes described. According to obtained data for the both states, the fine individual particles of the eutectic Ca-containing intermetallics (dark in appearance) with a less than $1 \mu \mathrm{m}$ size can be detected at sub-grain boundaries confirming their high pinning ability. However, detailed analysis revealed very few subtle particles in the $S 350^{\circ} \mathrm{C}$ state (Figure $5 \mathrm{~b}$ ) which can be attributed to the initial stage of $\mathrm{Ll}_{2}-\mathrm{Al}_{3} \mathrm{Zr}$ phase formation. This assumption meets well with the electrical conductivity data presented in Figure $4 \mathrm{~b}$. In contrast, for the $\mathrm{S} 450{ }^{\circ} \mathrm{C}$ state an exceptionally high number density and uniform distribution of the $\mathrm{L}_{2}-\mathrm{Al}_{3} \mathrm{Zr}$ phase nanoparticles are detected (Figure 5d,e). The result obtained suggests almost complete decomposition of the aluminum solid solution which converges well with data on the maximum electrical conductivity (Figure $4 b$ ) and hardness of the EMC rod (Figure 4a).

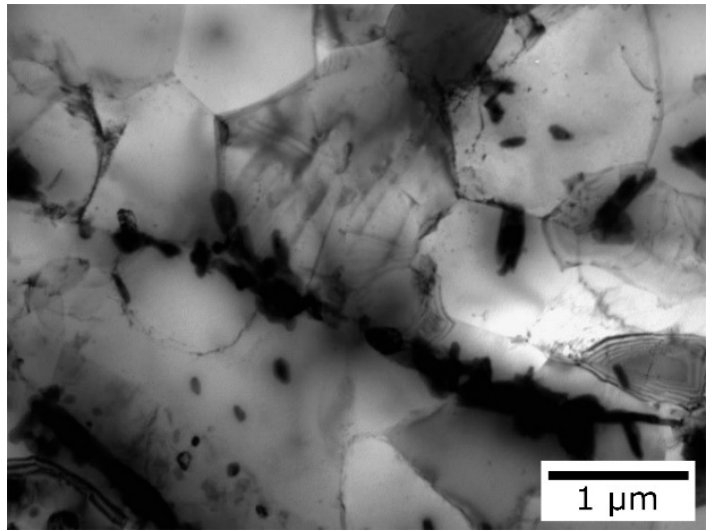

(a)

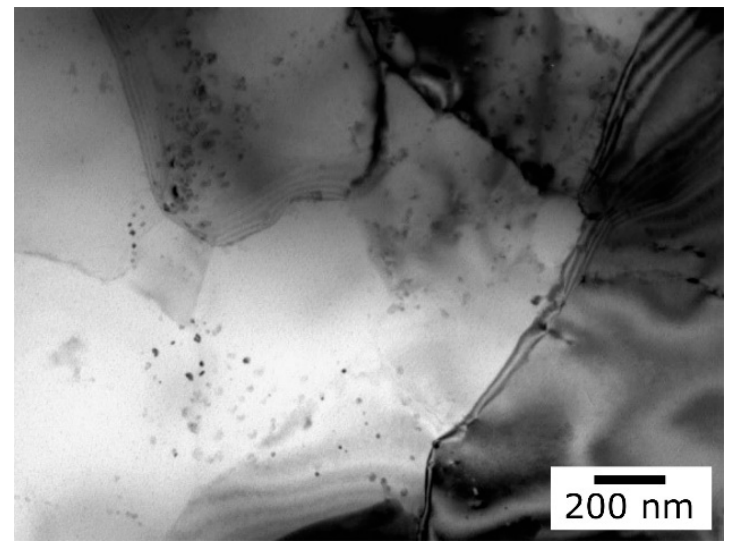

(b)

Figure 5. Cont. 


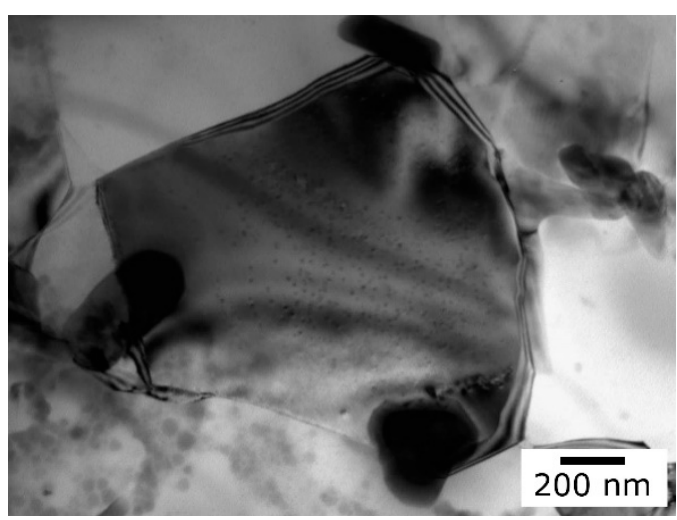

(c)

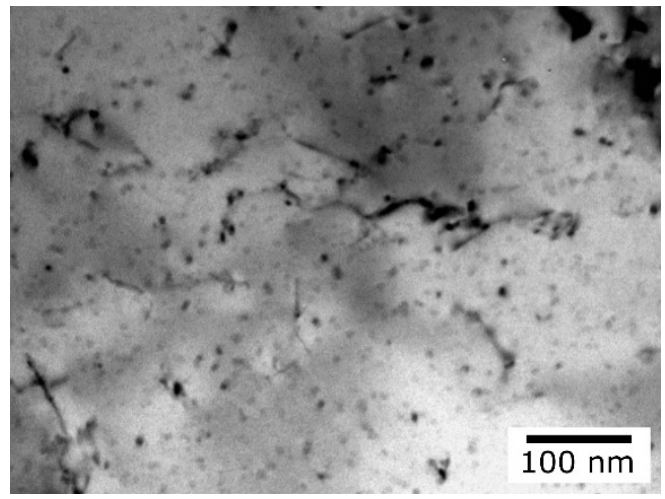

(d)

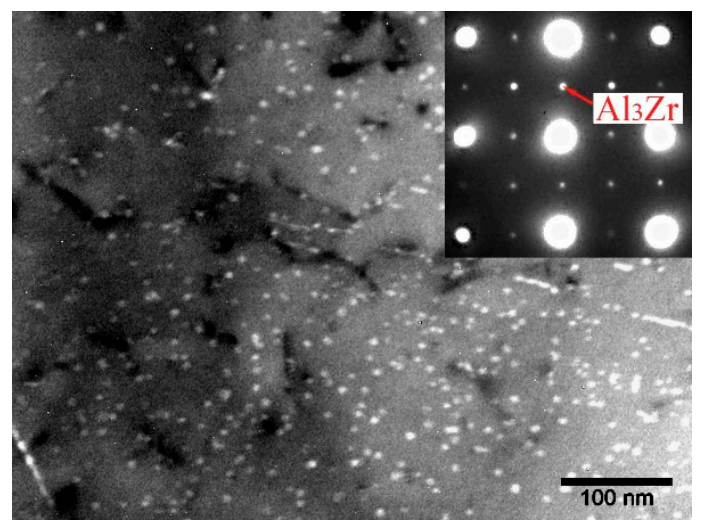

(e)

Figure 5. TEM structure of wire alloy ACZ (strip) and after annealing according to $(\mathbf{a}, \mathbf{b}) \mathrm{S} 350{ }^{\circ} \mathrm{C}$ and $(\mathbf{c}-\mathbf{e}) \mathrm{S} 450{ }^{\circ} \mathrm{C}$ regimes, (a-d) bright field, (e) dark field and diffraction patterns.

\subsection{Properties of Wire}

Mechanical and electrical properties of the wire ACZ alloy in as-drawn and annealed states are given in Table 3. In the initial state, the alloy has a good combination of strength (UTS $~ 280 \mathrm{MPa}$ and YS $250 \mathrm{MPa}$ ) and ductility (El 4\%), however, the electrical conductivity is small ( $\sim 3 \%$ IACS). Annealing of the $3 \mathrm{~mm}$ wire according to the modes given in Table 2 allows one to increase the EC value significantly. In this case, the EC values are approximately the same as for the cold rolled strip (Figure $4 \mathrm{~b}$ ). This suggests that the decomposition of $(\mathrm{Al})$ proceeds in a similar way. As can be seen from Table 3, the experimental alloy in the W450 state has the best combination of strength (UTS $200 \mathrm{MPa}$ and $\mathrm{YS} \sim 180 \mathrm{MPa}$ ), elongation (El 12\%) and electrical conductivity (54.7\% IACS).

Fractography of wire samples after a tensile test revealed a fine-dimpled ductile structure of the fracture surface (Figure 6). Calcium-bearing particles found inside the dimples (Figure 6a,b, BSE mode) are much smaller than the average diameter of the dimples. It should also be noted that no oxides or nonmetallic inclusions were observed which meets well with a previous study [22] confirming melt refining tendency when using EMC technology. 


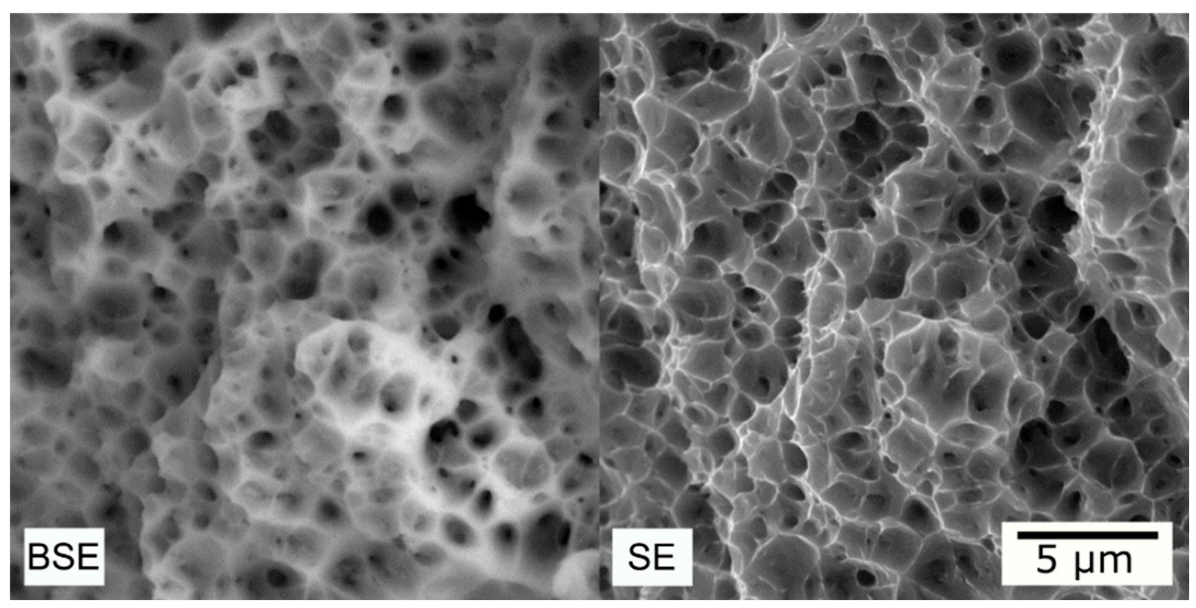

(a)

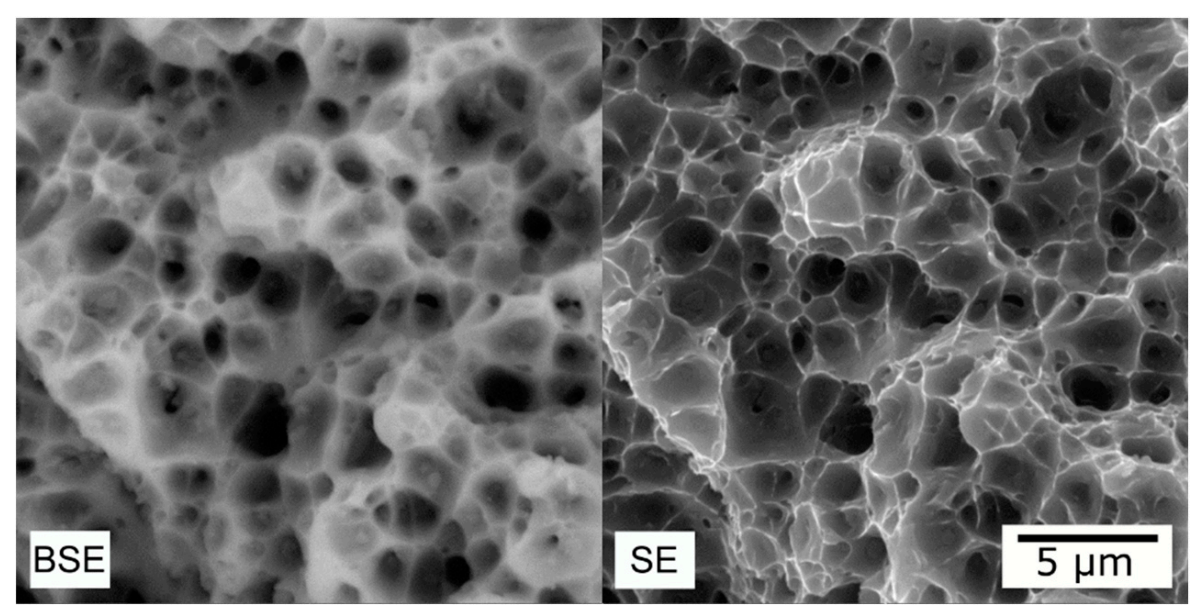

(b)

Figure 6. Fracture surfaces of experimental wire alloy (a) in initial (W) and (b) annealed (W450) states, SEM, left—backscattered electron image, right—secondary electron image, SEM.

\section{Discussion}

When comparing the basic characteristics of the new ACZ alloy and the previously studied $\mathrm{Al}-0.6 \% \mathrm{Zr}-0.4 \% \mathrm{Fe}-0.4 \% \mathrm{Si}$ alloy [22] obtained under the same conditions, it can be seen that at close values of strength and electrical conductivity, the heat resistance of the Ca-containing alloy is significantly higher $\left(450\right.$ vs. $\left.400^{\circ} \mathrm{C}\right)$ despite a smaller content of $\mathrm{Zr}$ (0.5 vs. $0.6 \mathrm{wt} . \%)$. Indeed, the hardness of the Ca-free alloy decreases down to $40 \mathrm{HV}$ after annealing at $450{ }^{\circ} \mathrm{C}$, which is significantly lower than that for the new alloy with calcium (Table 3). Obviously, the reason for the increase in the heat resistance is that the ACZ alloy contains calcium. Therefore, study of the effect of this element deserves special consideration. Considering that zirconium forms only the $\mathrm{Al}_{3} \mathrm{Zr}$ phase (stable and metastable modifications), to understand the distribution of calcium, iron and silicon between phases, it is necessary to consider the Al-Ca-Fe-Si system. Earlier [26], the structure of this phase diagram in the range of $\mathrm{Al}-\mathrm{Ca}$ alloys (concentration of Ca much higher than $\mathrm{Fe}$ and $\mathrm{Si}$ ) was reviewed but other fields (with small Ca content) were not studied. Using the calculation in the Thermo-Calc software [31], as well as the results of previously published works [22,24-26,30,32] and additional experiments, we proposed structures of the Al-Ca-Fe-Si system in the aluminum corner including distribution of phases in the solid state (Figure 7a) and polythermal projection (Figure 7b). According to the proposed version, this system contains five four-phase regions: $\mathrm{I}-(\mathrm{Al})+\mathrm{Al}_{4} \mathrm{Ca}+$ 
$\mathrm{Al}_{10} \mathrm{CaFe}_{2}+\mathrm{Al}_{2} \mathrm{CaSi}_{2}, \mathrm{II}-(\mathrm{Al})+\mathrm{Al}_{10} \mathrm{CaFe}_{2}+\mathrm{Al}_{2} \mathrm{CaSi}_{2}+\mathrm{Al}_{3} \mathrm{Fe}, \mathrm{III}-(\mathrm{Al})+\mathrm{Al}_{2} \mathrm{CaSi}_{2}+$ $\mathrm{Al}_{3} \mathrm{Fe}+\mathrm{Al}_{8} \mathrm{Fe}_{2} \mathrm{Si}, \mathrm{IV}-(\mathrm{Al})+\mathrm{Al}_{2} \mathrm{CaSi}_{2}+\mathrm{Al}_{8} \mathrm{Fe}_{2} \mathrm{Si}+\mathrm{Al}_{5} \mathrm{FeSi}, \mathrm{V}-(\mathrm{Al})+\mathrm{Al}_{2} \mathrm{CaSi}_{2}+\mathrm{Al}_{5} \mathrm{FeSi}$ $+(\mathrm{Si})$. From the distribution shown in Figure 7a it follows that the $\mathrm{Al}_{2} \mathrm{CaSi}_{2}$ phase is present in all regions of this quaternary system. Considering the low solubility of $\mathrm{Ca}$ in (Al), this means that even at a small amount of calcium in Fe and Si containing alloys, the formation of this particular ternary compound is inevitable. Excess calcium should lead to the formation of the $\mathrm{Al}_{4} \mathrm{Ca}$ and $\mathrm{Al}_{10} \mathrm{CaFe}_{2}$ phases. The influence of calcium on the equilibrium phase composition of the $\mathrm{Al}-0.5 \% \mathrm{Fe}-0.25 \% \mathrm{Si}$ alloy (i.e., with the same concentrations as in the ACZ alloy) is reflected in Table 4. The calculation results show that the phase composition of the base ternary alloy has a very high sensitivity to the calcium content. In this case, the ACZ alloy must certainly be in region I. However, for nonequilibrium solidification, the phase composition can differ greatly from the equilibrium one. This is largely due to the occurrence of incomplete peritectic reactions. As follows from the polythermal projection (Figure $7 \mathrm{~b}$ ), there are three invariant peritectic and three eutectic reactions in the aluminum corner of the $\mathrm{Al}-\mathrm{Ca}-\mathrm{Fe}-\mathrm{Si}$ system. The compositions of the liquid phase and the temperatures of these reactions are given in Table 5.

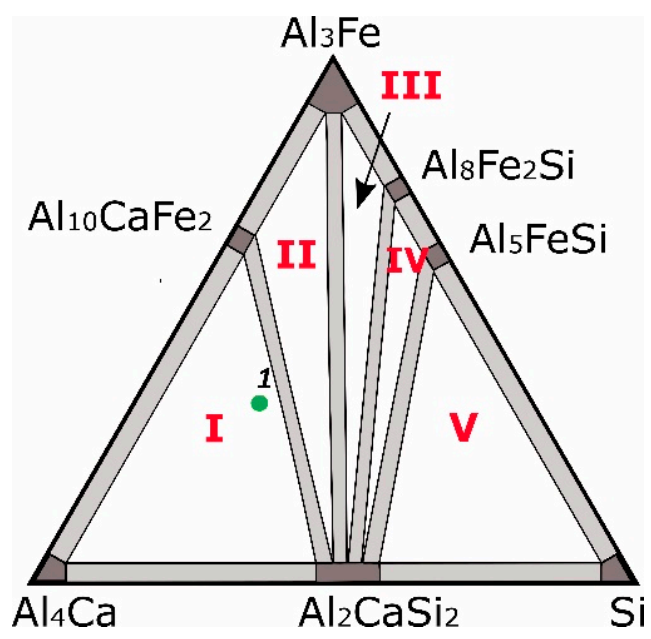

(a)

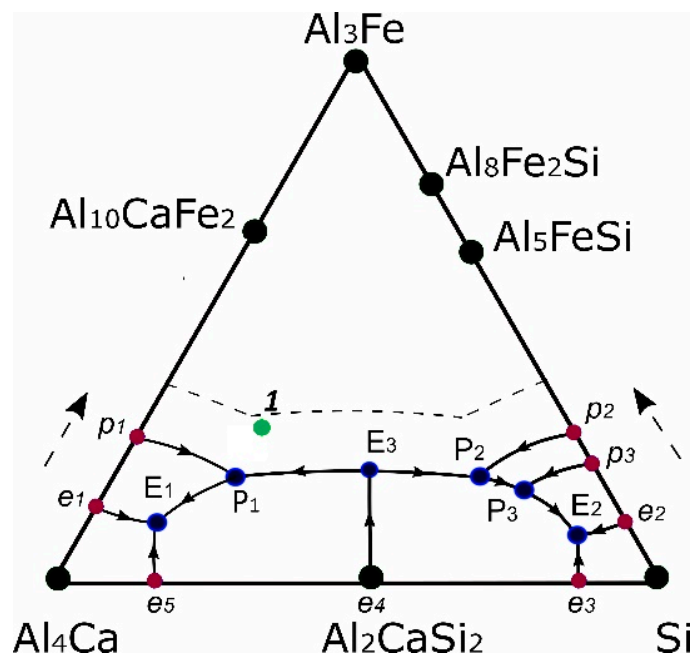

(b)

Figure 7. Phase diagram of $\mathrm{Al}-\mathrm{Ca}-\mathrm{Fe}-\mathrm{Si}$ system in aluminum corner: (a) distribution of phases in in the solid state and (b) polythermal projection. Point 1 corresponds to the chemical composition of the ACZ alloy. 
Table 4. Effect of Ca concentration on phase composition of alloy $\mathrm{Al}-0.5 \% \mathrm{Fe}-0.25 \% \mathrm{Si}$ (calculated at $200{ }^{\circ} \mathrm{C}$ ).

\begin{tabular}{ccc}
\hline Concentration of Ca, wt.\% & Phase Field & Designation in Figure 7a \\
\hline $0-<0.01$ & $(\mathrm{Al})+\mathrm{Al}_{8} \mathrm{Fe}_{2} \mathrm{Si}+\mathrm{Al}_{5} \mathrm{FeSi}$ & - \\
$<0.01-0.10$ & $(\mathrm{Al})+\mathrm{Al}_{2} \mathrm{CaSi}_{2}+\mathrm{Al}_{8} \mathrm{Fe}_{2} \mathrm{Si}+\mathrm{Al}_{5} \mathrm{FeSi}$ & $\mathrm{IV}$ \\
$0.10-0.18$ & $(\mathrm{Al})+\mathrm{Al}_{2} \mathrm{CaSi}_{2}+\mathrm{Al}_{8} \mathrm{Fe}_{2} \mathrm{Si}$ & $\mathrm{IV} / \mathrm{III}$ \\
& $(\mathrm{Al})+\mathrm{Al}_{2} \mathrm{CaSi}_{2}+\mathrm{Al}_{3} \mathrm{Fe}+\mathrm{Al}_{8} \mathrm{Fe}_{2} \mathrm{Si}$ & $\mathrm{III}$ \\
$0.18-0.38$ & $(\mathrm{Al})+\mathrm{Al}_{2} \mathrm{CaSi}_{2}+\mathrm{Al}_{3} \mathrm{Fe}$ & $\mathrm{III} / \mathrm{II}$ \\
& $(\mathrm{Al})+\mathrm{Al}_{10} \mathrm{CaFe}_{2}+\mathrm{Al}_{2} \mathrm{CaSi}_{2}+\mathrm{Al}_{3} \mathrm{Fe}$ & $\mathrm{II}$ \\
& $(\mathrm{Al})+\mathrm{Al}_{10} \mathrm{CaFe}_{2}+\mathrm{Al}_{2} \mathrm{CaSi}_{2}$ & $\mathrm{II} / \mathrm{I}$ \\
$\mathrm{I}$ & $(\mathrm{Al})+\mathrm{Al}_{4} \mathrm{Ca}+\mathrm{Al}_{10} \mathrm{CaFe}_{2}+\mathrm{Al}_{2} \mathrm{CaSi}_{2}$ & $\mathrm{I}$ \\
\hline
\end{tabular}

Table 5. Calculated parameters of invariant reactions in the $\mathrm{Al}-\mathrm{Ca}-\mathrm{Fe}-\mathrm{Si}$ system.

\begin{tabular}{|c|c|c|c|c|c|c|}
\hline \multirow{2}{*}{ Reaction } & \multirow{2}{*}{$\mathrm{T},{ }^{\circ} \mathrm{C}$} & \multirow{2}{*}{ Point in Figure $7 b$} & \multicolumn{4}{|c|}{ Concentration in Liquid, wt.\% } \\
\hline & & & $\mathrm{Ca}$ & $\mathrm{Fe}$ & Si & Al \\
\hline $\mathrm{L} \rightarrow(\mathrm{Al})+\mathrm{Al}_{4} \mathrm{Ca}+\mathrm{Al}_{10} \mathrm{CaFe}_{2}+\mathrm{Al}_{2} \mathrm{CaSi}_{2}$ & 611 & $\mathrm{E}_{1}$ & 6.92 & 0.68 & 0.50 & - \\
\hline $\mathrm{L} \rightarrow(\mathrm{Al})+\mathrm{Al}_{5} \mathrm{FeSi}+(\mathrm{Si})+\mathrm{Al}_{2} \mathrm{CaSi}_{2}$ & 576 & $\mathrm{E}_{2}$ & $<0.01$ & 0.84 & 12.48 & 86.68 \\
\hline $\mathrm{L} \rightarrow(\mathrm{Al})+\mathrm{Al}_{3} \mathrm{Fe}+\mathrm{Al}_{2} \mathrm{CaSi}_{2} 1$ & 632 & $E_{3}$ & 1.52 & 1.61 & 2.24 & 94.63 \\
\hline $\mathrm{L}+\mathrm{Al}_{3} \mathrm{Fe} \rightarrow(\mathrm{Al})+\mathrm{Al}_{10} \mathrm{CaFe}_{2}+\mathrm{Al}_{2} \mathrm{CaSi}_{2}$ & $\sim 620$ & $\mathrm{P}_{1}$ & $\sim 6$ & $\sim 1$ & $\sim 1$ & $\sim 92$ \\
\hline $\mathrm{L}+\mathrm{Al}_{3} \mathrm{Fe} \rightarrow(\mathrm{Al})+\mathrm{Al}_{8} \mathrm{Fe}_{2} \mathrm{Si}+\mathrm{Al}_{2} \mathrm{CaSi}_{2}$ & 629 & $\mathrm{P}_{2}$ & 0.60 & 1.90 & 3.69 & 93.91 \\
\hline $\mathrm{L}+\mathrm{Al}_{8} \mathrm{Fe}_{2} \mathrm{Si} \rightarrow(\mathrm{Al})+\mathrm{Al}_{5} \mathrm{FeSi}+\mathrm{Al}_{2} \mathrm{CaSi}_{2}$ & 612 & $\mathrm{P}_{3}$ & 0.07 & 1.60 & 7.10 & 91.23 \\
\hline
\end{tabular}

${ }^{1}$ In quasi-ternary section.

As follows from the polythermal projection (Figure $7 \mathrm{~b}$ ), in a quaternary alloy containing $0.8 \% \mathrm{Ca}, 0.5 \% \mathrm{Fe}$ and $0.25 \% \mathrm{Si}$ (point 1 in Figure $7 \mathrm{~b}$ ), after primary crystallization of $(\mathrm{Al})$, eutectic reactions $\mathrm{L} \rightarrow(\mathrm{Al})+\mathrm{Al}_{3} \mathrm{Fe}$ and $\mathrm{L} \rightarrow(\mathrm{Al})+\mathrm{Al}_{3} \mathrm{Fe}+\mathrm{Al}_{2} \mathrm{CaSi}_{2}$ (line $\mathrm{E}_{3}-\mathrm{P}_{1}$ ), and then peritectic $\mathrm{L}+\mathrm{Al}_{3} \mathrm{Fe} \rightarrow(\mathrm{Al})+\mathrm{Al}_{10} \mathrm{CaFe}_{2}+\mathrm{Al}_{2} \mathrm{CaSi}_{2}$ (point $\mathrm{P}_{1}$ ) one should proceed. The incompleteness of the latter explains the presence of needle-like particles in the microstructure of the slowly solidified ACZ alloy (Figure 2d). With an increase in the cooling rate, the phase boundaries shift towards higher iron content (dashed line in Figure $7 \mathrm{~b}$ ), therefore the $\mathrm{Al}_{3} \mathrm{Fe}$ phase is not formed and it is absent in the as-cast microstructure of the EMC rod (Figure 2a,b). The solidification of this quaternary alloy (and hence the ACZ alloy) should end via eutectic reactions with the formation of three Ca-containing phases (point $\mathrm{P}_{1}$ ). To further confirm the proposed structure of the Al-Ca-Fe-Si system, several quaternary alloys were annealed at $600{ }^{\circ} \mathrm{C}$. As can be seen from Figure $8 \mathrm{a}$, in the alloy containing $0.8 \% \mathrm{Ca}, 0.5 \% \mathrm{Fe}$ and $0.25 \% \mathrm{Si}$, only globular particles are detected, which, according to the distribution maps for Ca (Figure 8b), Fe (Figure 8c) and Si (Figure 8d) elements, can be identified as $\mathrm{Al}_{4} \mathrm{Ca}, \mathrm{Al}_{10} \mathrm{CaFe}_{2}$ and $\mathrm{Al}_{2} \mathrm{CaSi}_{2}$.

To confirm the effect of cold deformation on the electrical conductivity of the ACZ alloy mentioned above, additional studies on the effect of calcium on EC of both as-cast ingots and cold rolled sheets containing $0.5 \% \mathrm{Fe}$ and $0.25 \% \mathrm{Si}$ at varying calcium concentrations (Table 1) were carried out (Figure 9). As can be seen from Figure 9, the difference between the ingot and cold rolled sheet is small at small Ca content but at $0.75-1 \%$ Ca it reaches $\sim 2 \mathrm{MS} / \mathrm{m}$, i.e., similar to the ACZ alloy (Figure $4 \mathrm{~b}$ ). Taking into account the low solubility of $\mathrm{Ca}$ in $(\mathrm{Al})$ and the invariability of the phase composition during deformation, this effect can probably be caused by the influence of the dislocation structure, vacancies and other defects of the crystal structure. This requires special study. A slight increase in EC should be noted with the addition of $0.1 \%$ Ca to the ternary alloy. This can be explained by a decrease in the concentration of $\mathrm{Si}$ in $(\mathrm{Al})$ due to the formation of $\mathrm{Al}_{2} \mathrm{CaSi}_{2}$ compound. 


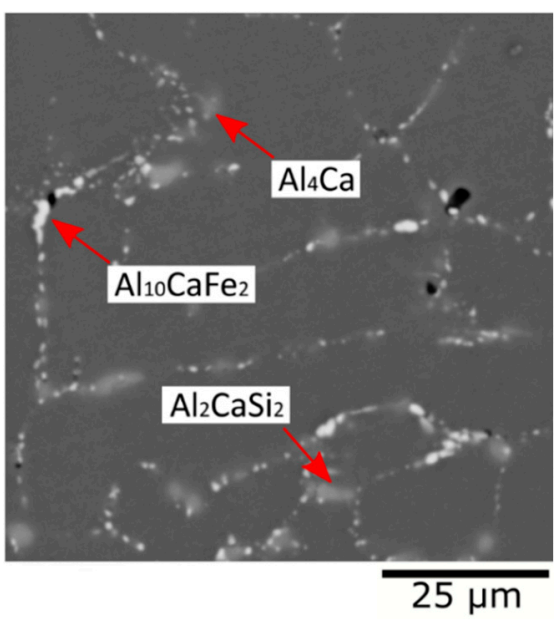

(a)

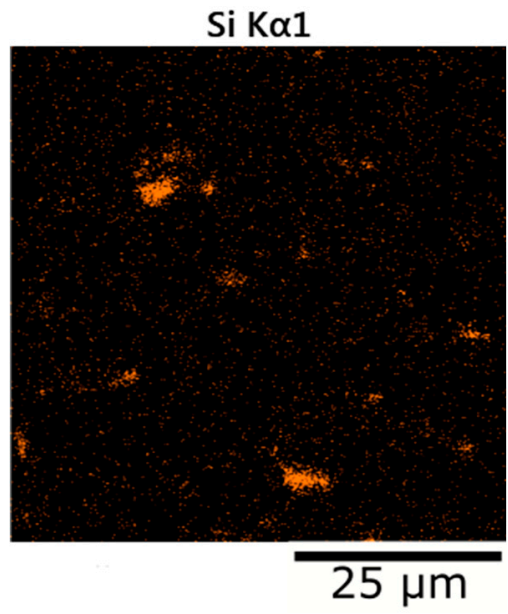

(c)

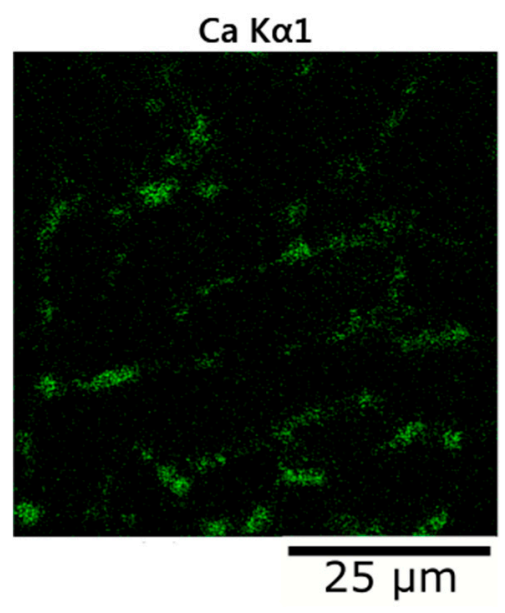

(b)

\section{Fe Ka1}

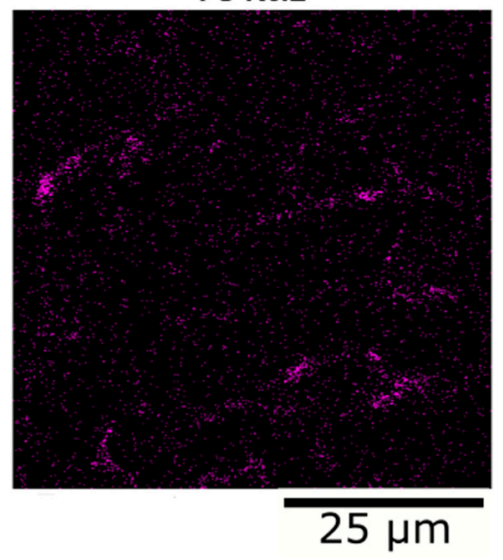

(d)

Figure 8. Microstructure of alloy Al-1\% Ca-0.5\% Fe-0.25\% Si (ingot $10 \mathrm{~mm} \times 40 \mathrm{~mm} \times 200 \mathrm{~mm}$ ) after annealing at $600{ }^{\circ} \mathrm{C}$ : (a) SEM, (b-d) electron microprobe analysis (EMPA) mapping (b-Ca, c-Si, d-Fe).

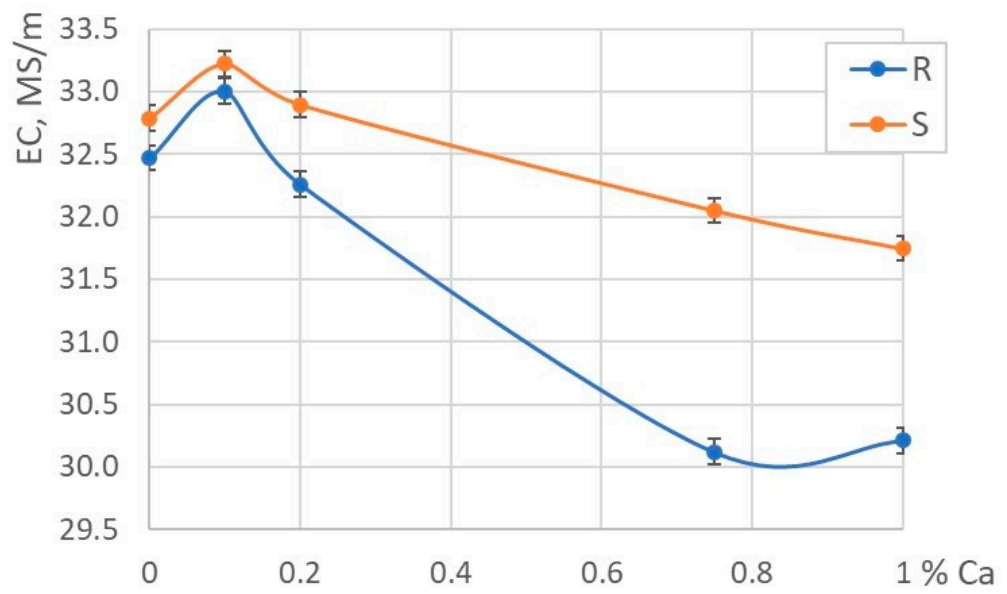

Figure 9. Electrical conductivity of Al-Ca-Fe-Si alloys containing $0.5 \%$ Fe and $0.25 \%$ Si vs. calcium content curves: R-EMC rod, S-cold rolled strip. 


\section{Summary}

1. Experimental aluminum alloy containing $0.8 \% \mathrm{Ca}, 0.5 \% \mathrm{Zr}, 0.5 \% \mathrm{Fe}$ and $0.25 \% \mathrm{Si}$ (wt.\%) in the form of a long-length rod $12 \mathrm{~mm}$ in diameter and $\approx 20 \mathrm{~m}$ in length was manufactured using an electromagnetic casting (EMC) technique. The extremely high cooling rate during alloy solidification $\left(\approx 10^{4} \mathrm{~K} / \mathrm{s}\right)$ caused the formation of a favorable microstructure containing fine eutectic particles and full dissolution of $\mathrm{Zr}$ in Al solid solution. Due to the microstructure formed, the ingots possess high manufacturability for both cold drawing of a wire $3 \mathrm{~mm}$ in diameter and cold rolling of a strip in $2 \mathrm{~mm}$ in thickness.

2. EMC rod hardness reaches the highest value at $450{ }^{\circ} \mathrm{C}$ annealing temperature which is associated with the formation of the $\mathrm{L}_{2}$ type $\mathrm{Al}_{3} \mathrm{Zr}$ phase precipitates with an average diameter of 10-20 nm and a high number density. Decomposition of aluminum solid solution during annealing also promotes the increase in the electrical conductivity (EC). Further increase in the annealing temperature leads to significant softening due to the coarsening of the $\mathrm{Al}_{3} \mathrm{Zr}$ precipitation structure. Deformation hardening in the cold rolled strip can be maintained at up to $450{ }^{\circ} \mathrm{C}$ annealing, which is associated with the high pinning ability of zirconium and calcium containing phases: $\mathrm{Al}_{4} \mathrm{Ca}$, $\mathrm{Al}_{10} \mathrm{CaFe}_{2}$ and $\mathrm{Al}_{2} \mathrm{CaSi}_{2}$. Further increase in the annealing temperature leads to softening due to the recrystallization. The best combination of hardness and $\mathrm{EC}$ in the cold rolled strip was reached after annealing at $450^{\circ} \mathrm{C}$.

3. The general structure of $\mathrm{Al}-\mathrm{Ca}-\mathrm{Fe}-\mathrm{Si}$ system in the $\mathrm{Al}$ corner (including distribution of phases in the solid state and polythermal projection) was proposed.

4. The experimental wire alloy had the best combination of strength (UTS $=200 \mathrm{MPa}$, YS $=180 \mathrm{MPa}$ ), electrical conductivity (54.8\% IACS) and thermal stability (up to $450{ }^{\circ} \mathrm{C}$ ) as compared with alloys on the basis of Al-Zr and Al-REM systems.

5. It was shown that the presence of calcium in the model alloy increases the electrical conductivity after cold forming operations (both drawing and rolling).

Author Contributions: Conceptualization, N.B.; investigation, N.K. and M.M.; methodology, V.T. and T.A.; supervision, N.B.; writing-original draft, N.B.; investigation, A.F., writing-review and editing, M.M., T.A, and N.K. All authors have read and agreed to the published version of the manuscript.

Funding: The authors gratefully acknowledge the financial support of the Ministry of Science and Higher Education of the Russian Federation in the framework of Increase Competitiveness Program of MISiS (No. P02-2017-2-10) (TEM, tensile tests, discussion) and the Russian Science Foundation (project No. 20-79-00239) (SEM, hardness and electrical conductivity tests, calculations).

Institutional Review Board Statement: Not applicable.

Informed Consent Statement: Not applicable.

Data Availability Statement: Data are available from the corresponding author on reasonable request.

Acknowledgments: The results were obtained by using the equipment of RPC Magnetic hydrodynamics LLC, Krasnoyarsk, Russia; Institute of Physics of Advanced Materials, Ufa State Aviation Technical University, Ufa, Russia; and Department of metal forming, National University of Science and Technology MISiS, Moscow, Russia.

Conflicts of Interest: The authors declare no conflict of interest.

\section{References}

1. Polmear, I.J. Light Alloys. From Traditional Alloys to Nanocrystals, 5th ed.; Butterworth-Heinemann: Oxford, UK, 2006; pp. 129-130. Available online: https:/ / www.elsevier.com/books/light-alloys/polmear/978-0-08-099431-4 (accessed on 29 October 2020).

2. ASTM B941-16. Standard Specification for Heat Resistant Aluminum-Zirconium Alloy Wire for Electrical Purposes; ASTM International: West Conshohocken, PA, USA, 2016; pp. 1-4.

3. Brubak, J.P.; Eftestol, B.; Ladiszlaidesz, F. Aluminium Alloy, a Method of Making It and an Application of the Alloy. U.S. Patent 5,067,994, 26 November 1991. Available online: https:/ / patents.google.com/patent/US5067994A/en?oq=5067994 (accessed on 4 November 2020). 
4. Knych, T.; Jablonsky, M.; Smyrak, B. New aluminium alloys for electrical wires of fine diameter for automotive industry. Arch. Metall. Mater. 2009, 54,671-676. Available online: https://www.researchgate.net/publication/263734063_New_aluminium_ alloys_for_electrical_wires_of_fine_diameter_for_automotive_industry (accessed on 6 November 2020).

5. Orlova, T.S.; Mavlyutov, A.M.; Latynina, T.A.; Ubyivovk, E.V.; Murashkin, M.Y.; Schneider, R.; Gerthsen, D.; Valiev, R.Z. Influence of severe plastic deformation on microstructure strength and electrical conductivity of aged Al-0.4Zr (wt.\%) alloy. Rev. Adv. Mater. Sci. 2018, 55, 92-101. [CrossRef]

6. Belov, N.A.; Alabin, A.N.; Matveeva, I.A.; Eskin, D.G. Effect of Zr additions and annealing temperature on electrical conductivity and hardness of hot rolled Al sheets. Trans. Nonferrous Met. Soc. China 2015, 25, 2817-2826. [CrossRef]

7. Fu, J.; Yang, Z.; Deng, Y.; Wu, Y.; Lu, J. Influence of Zr addition on precipitation evolution and performance of Al-Mg-Si alloy conductor. Mater. Charact. 2020, 159, 110021. [CrossRef]

8. Knipling, K.E.; Karnesky, R.A.; Lee, C.P.; Dunand, D.C.; Seidman, D.N. Precipitation evolution in Al-0.1Sc, Al-0.1Zr and Al-0.1Sc-0.1Zr (at.\%) alloys during isochronal aging. Acta Mater. 2010, 58, 5184-5195. [CrossRef]

9. Deschamp, A.; Guyo, P. In situ small-angle scattering study of the precipitation kinetics in an Al-Zr-Sc alloy. Acta Mater. 2007, 55, 2775-2783. [CrossRef]

10. Lefebvre, W.; Danoix, F.; Hallem, H.; Forbord, B.; Bostel, A.; Marthinsen, K. Precipitation kinetic of $\mathrm{Al}_{3}(\mathrm{Sc}, \mathrm{Zr})$ dispersoids in aluminium. J. Alloys Compd. 2009, 470, 107-110. [CrossRef]

11. Forbord, B.; Lefebvre, W.; Danoix, F.; Hallem, H.; Marthinsen, K. Three dimensional atom probe investigation on the formation of $\mathrm{Al}_{3}(\mathrm{Sc}, \mathrm{Zr}$ )-dispersoids in aluminium alloys. Scr. Mater. 2004, 51, 333-337. [CrossRef]

12. Clouet, E.; Barbu, A.; Lae, L.; Martin, G. Precipitation kinetics of $\mathrm{Al}_{3} \mathrm{Zr}$ and $\mathrm{Al}_{3} \mathrm{Sc}$ in aluminum alloys modeled with cluster dynamics. Acta Mater. 2005, 53, 2313-2325. [CrossRef]

13. Çadırl, E.; Tecer, H.; Sahin, M.; Yılmaz, E.; Kırındı, T.; Gündüz, M. Effect of heat treatments on the microhardness and tensile strength of Al-0.25 wt.\% Zr alloy. J. Alloys Compd. 2015, 632, 229-237. [CrossRef]

14. Robson, J.D.; Prangnell, P.B. Dispersoid precipitation and process modelling in zirconium containing commercial aluminium alloys. Acta Mater. 2001, 49, 599-613. [CrossRef]

15. Gao, T.; Ceguerra, A.; Breen, A.; Liu, X.; Wu, Y.; Ringer, S. Precipitation behaviors of cubic and tetragonal Zr-rich phase in Al-Si-Zr alloys. J. Alloys Compd. 2016, 674, 125-130. [CrossRef]

16. Yea, J.; Guana, R.; Zhaoa, H.; Yinc, A. Effect of Zr content on the precipitation and dynamic softening behavior in Al-Fe-Zr alloys. Mater. Charact. 2020, 162, 110-181. [CrossRef]

17. Vlach, M.; Stulíková, I.; Smola, B.; Žaludová, N.; Černá, J. Phase transformations in isochronally annealed mould-cast and cold-rolled Al-Sc-Zr-based alloy. J. Alloys Compd. 2010, 492, 143-148. [CrossRef]

18. Belov, N.A.; Korotkova, N.O.; Alabin, A.N.; Mishurov, S.S. Influence of a silicon additive on resistivity and hardness of the Al-1\% Fe- $0.3 \%$ Zr alloy. Russ. J. Non-Ferrous Met. 2018, 59, 276-283. [CrossRef]

19. Knych, T.; Piwowarska, M.; Uliasz, P. Studies on the process of heat treatment of conductive AlZr alloys obtained in various productive processes. Arch. Metal Mater. 2011, 56, 687-692. [CrossRef]

20. Avdulov, A.A.; Usynina, G.P.; Sergeev, N.V.; Gudkov, I.S. Otlichitel'nyye osobennosti struktury I svoystv dlinnomernykh slitkov malogo secheniya iz alyuminiyevykh splavov, otlitykh $\mathrm{v}$ elektromagnitnyy kristallizator. [Distinctive features of the structure and properties of long ingots of small cross section from aluminum alloys cast in an electromagnetic mold]. Tsvet. Met. 2017, 7, 73-77. [CrossRef]

21. Dobatkin, V.I.; Elagin, V.I.; Fedorov, V.M. Bystrozakristallizovannye Alyuminievye Splavy (Rapidly Solidified Aluminum Alloys); VILS: Moscow, Russia, 1995; pp. 43-59.

22. Belov, N.A.; Murashkin, M.Y.; Korotkova, N.O.; Akopyan, T.K.; Timofeev, V.N. Structure and properties of Al-0.6wt.\%Zr(Fe,Si) wire alloy manufactured by direct drawing of electromagnetically cast wire rod. Metals 2020, 10, 769. [CrossRef]

23. Korotkova, N.O.; Belov, N.A.; Timofeev, V.N.; Motkov, M.M.; Cherkasov, S.O. Influence of heat treatment on the structure and properties of an Al-7\% REM conductive aluminum alloy casted in an electromagnetic crystallizer. Phys. Met. Metallogr. 2020, 121, 173-179. [CrossRef]

24. Belov, N.A.; Akopyan, T.K.; Korotkova, N.O.; Naumova, E.A.; Pesin, A.M.; Letyagin, N.V. Structure and properties of Al-Ca(Fe, $\mathrm{Si}, \mathrm{Zr}, \mathrm{Sc}$ ) wire alloy manufactured from as-cast billet. JOM 2020, 72, 3760-3768. [CrossRef]

25. Korotkova, N.O.; Belov, N.A.; Avxentieva, N.N.; Aksenov, A.A. Effect of calcium additives on the phase compositionand physicomechanical properties of a conductive alloy Al-0.5\% Fe-0.2\% Si-0.2\% Zr-0.1\% Sc. Phys. Met. Metallogr. 2020, 121, 95-101. [CrossRef]

26. Belov, N.A.; Naumova, E.A.; Akopyan, T.K.; Doroshenko, V.V. Phase diagram of the Al-Ca-Fe-Si system and its application for the design of aluminum matrix composites. JOM 2018, 70, 2710-2715. [CrossRef]

27. RPC Magnetic Hydrodynamics LLC. Available online: http:/ / www.npcmgd.com (accessed on 10 November 2020).

28. IEC 60468:1974. Method of Measurement of Resistivity of Metallic Materials, 1st ed.; IEC: Geneva, Switzerland, 1974; pp. 1-31.

29. Bäckerud, L.; Chai, G.; Tamminen, J. Solidification Characteristics of Aluminum Alloys. Vol. 1: Foundry Alloys; Skanaluminium: Oslo, Norway, 1986; pp. 9-26.

30. Glazoff, M.V.; Khvan, A.V.; Zolotorevsky, V.S.; Belov, N.A.; Dinsdale, A.T. Casting Aluminum Alloys. Their Physical and Mechanical Metallurgy; Elsevier: Oxford, UK, 2019; pp. 180-192. 
31. Thermo-Calc Software-Computational Materials Engineering. Available online: http://www.thermocalc.com (accessed on 1 December 2020).

32. Belov, N.A.; Eskin, D.G.; Aksenov, A.A. Multicomponent Phase Diagrams: Applications for Commercial Aluminum Alloys; Elsevier: Amsterdam, The Netherlands, 2005; pp. 19-31. 